\title{
Consequences of protein supplementation for anorexia, expression of immunity and plasma leptin concentrations in parasitized ewes of two breeds
}

\author{
Konstantinos Zaralis ${ }^{1}$ *, Bert J. Tolkamp ${ }^{1}$, Jos G. M. Houdijk ${ }^{1}$, Alastair R. G. Wylie ${ }^{2,3}$ and Ilias Kyriazakis ${ }^{1,4}$ \\ ${ }^{1}$ Animal Nutrition and Health Department, Scottish Agricultural College, Kings Buildings, Edinburgh EH9 3JG, UK \\ ${ }^{2}$ Agri-food and Biosciences Institute, Newforge Lane, Belfast BT9 5PX, UK \\ ${ }^{3}$ The Queen's University of Belfast, Belfast BT9 5PX, UK \\ ${ }^{4}$ Veterinary Faculty, University of Thessaly, PO Box 199, 43100 Karditsa, Greece
}

(Received 11 January 2008 - Revised 9 May 2008 - Accepted 20 May 2008 - First published online 1 July 2008)

The periparturient relaxation of immunity (PPRI) against parasites in ewes has a nutritional basis. We investigated whether ewes experience a reduction in food intake (anorexia) during PPRI and if the magnitude of anorexia is affected by host production potential and dietary protein supplementation. We also investigated whether nematode infection is linked to plasma leptin concentrations in periparturient ewes. The experiment was a $2 \times 2 \times 2$ factorial design. Two breeds of twin-bearing/lactating ewes (Greyface cross, G $(n$ 32) and Scottish Blackface, B ( $n$ 32)) were used. Half of the ewes were trickle infected with 30000 larvae of the abomasal parasite Teladorsagia circumcincta per week and the other half were not. During the experiment, all ewes had ad libitum access to a low-protein diet that provided less protein than the recommended allowance. In addition, half of the ewes received a protein supplement that resulted in protein intakes that exceeded recommendations. Nematode infection resulted in a breakdown of immunity to parasites and a reduction in food intake in both breeds. The breeds differed in the extent of PPRI (G ewes having higher faecal egg counts than B ewes), but not in the magnitude of anorexia. Protein supplementation resulted in a reduction in faecal egg counts, but had no effect on the magnitude of anorexia. Plasma leptin concentrations changed significantly over time, but were not affected by protein supplementation or infection. It is concluded that infection with $T$. circumcincta in periparturient ewes results in anorexia that is not alleviated by protein supplementation and seems unrelated to plasma leptin concentrations.

Food intake: Leptin: Breed: Teladorsagia circumcincta

Anorexia, i.e. a reduction in voluntary food intake, is a prominent feature of many infections, including gastrointestinal parasitism. In sheep, the occurrence of anorexia after nematode infection has been investigated mainly in parasite-naïve lambs ${ }^{(1)}$ and such studies have shown that food intake returns to normal when animals acquire a full immunity to the parasites ${ }^{(2,3)}$. Reproductive ewes, however, can experience a breakdown of their acquired immunity to parasites during their periparturient period (from late pregnancy through to early lactation) and this is generally referred to as the 'periparturient relaxation of immunity' (PPRI). The phenomenon manifests as an increase in faecal egg counts (FEC) and worm burdens ${ }^{(4-6)}$. However, there is scant evidence whether or not ewes experience a reduction in food intake during PPRI. In addition, it is unknown whether there are differences between breeds in the degree of anorexia during PPRI and whether these are linked to the production potential of the breeds.

Coop \& Kyriazakis $^{(7)}$, while developing a nutrient partitioning framework that accounts for nutrient allocation towards the various physiological functions of the host, have suggested that PPRI has a nutritional basis. A number of studies have shown that the extent of the PPRI can be reduced by an increased intake of metabolizable protein $(\mathrm{MP})^{(8,9)}$. Whether enhanced protein nutrition affects the degree of anorexia in infected periparturient ewes is not known. In addition, it has been suggested that breeds that have been selected more intensively for production traits (e.g. growth) are more susceptible to gastrointestinal infections than breeds that have been selected less intensively ${ }^{(10-12)}$. Whether or not such breed differences in production potential are reflected in the degree of anorexia following infection, is not known.

Maternal plasma leptin concentrations (PLC) in noninfected ewes decline progressively during late pregnancy and early lactation ${ }^{(13)}$ and it has been suggested that this reduction in leptin could have negative effects on immune function $^{(14)}$. Adipose tissue metabolism plays an important role in the regulation of immune responses ${ }^{(15)}$ and increased PLC as a result of infection or inflammation have been observed in many models of disease ${ }^{(16,17)}$. Although a similar role for leptin has been suggested for nematode-infected ewes by Valderrabano et al. ${ }^{(18)}$, this was not based on a comparison of leptin concentrations between infected and uninfected ewes.

Abbreviations: ADFI, average daily food intake; B ewe, Scottish Blackface ewe; BCS, body condition score; BW, body weight; FEC, faecal egg counts; G ewe, Greyface cross ewe; HP treatment, high-protein treatment; LP treatment, low-protein treatment; MP, metabolizable protein; PLC, plasma leptin concentrations PPRI, periparturient relaxation of immunity; RFI, relative food intake; + treatment, nematode treatment; - treatment, no nematode treatment.

* Corresponding author: Dr Konstantinos Zaralis, fax +44 7713 15353121, email Konstantinos.Zaralis@sac.ac.uk 
The aim of the present study was to test the hypotheses that (1) nematode infected ewes experience anorexia during the occurrence of PPRI and the magnitude of anorexia is greater in ewes selected more intensively for high productivity than in ewes that have been selected less intensively, (2) the degree of anorexia can be reduced by dietary protein supplementation and (3) nematode infection of periparturient ewes will result in increased PLC compared to non-infected periparturient ewes.

\section{Materials and methods}

The Animal Experiments Committee of the Scottish Agricultural College approved the experimental protocol (AE ED 02/2005). The experiment was carried out under Home Office authority for experimental parasitic infection and repeated blood sampling (PPL 60/3004).

\section{Animals, housing and husbandry}

Sixty-four pregnant ewes, thirty-two Greyface crosses (G) and thirty-two Scottish Blackface (B), which were identified by scanning as bearing twins, were brought indoors $57 \mathrm{~d}$ $\left(d_{-57}\right)$ before the realized mean parturition day $\left(d_{0}\right)$. Upon housing, ewes were orally drenched with Ivermectin (Oramec, Merial, UK) and Levamisole (Nilverm Gold, Schering-Plough, Welwyn Garden City, UK) according to manufacturers' instructions, in order to remove residual worm burdens from previous exposure to parasites. The mean body weight (BW) and body condition score (BCS) at $\mathrm{d}_{-57}$ were 73.1 (SE 1.13) kg and 3.1 (SE 0.04) and 53.2 (SE 1.00) kg and 2.5 (SE 0.04) for $\mathrm{G}$ and $\mathrm{B}$ ewes, respectively. Ewes were housed in a naturally illuminated and ventilated shed in individual pens with solid floors until 5 weeks into lactation $\left(d_{35}\right)$. The pens were $1.5 \times 2.0 \mathrm{~m}$ and were bedded with a thick layer of sawdust that was topped up when required. Each pen was equipped with two feeding bins and ewes had free access to water from a bucket all day. Feeding bins were raised above floor level, a practice which prevented lambs from consuming any of the feed offered to the ewes.

\section{Experimental design}

Ewes were assigned randomly to treatments on the basis of their $\mathrm{BW}$ and $\mathrm{BCS}$ measured on $\mathrm{day}_{-57}$, and ensuring that an equal number $(n 8)$ of similar ewes of each breed were allocated to each treatment. The experimental design was a $2 \times 2 \times 2$ factorial, which involved the two breeds of sheep, two levels of infection (infected and uninfected controls) and two feeding treatments (protein supplemented and unsupplemented).

Infection treatments and infection details. The ewes were expected to have had previous exposure to gastrointestinal nematodes from field infections prior to housing. Following a $10 \mathrm{~d}$ adaptation period after housing, half of the ewes in each breed was trickle-infected (treatment: + ) with the gastrointestinal nematode Teladorsagia circumcincta at a dose of 10000 infective third-stage larvae, in $10 \mathrm{ml}$ water, each Monday, Wednesday and Friday until the end of the experiment. Similar rates of infection have previously been shown to lead to establishment of a patent $T$. circumcincta worm burden in periparturient ewes ${ }^{(6,19)}$. The larvae were incubated from eggs that were harvested from fresh faeces of infected whether donor sheep every $14 \mathrm{~d}$. Non-infected ewes (treatment: -) were given a similar volume of water only (sham infection) at the same time, thus undergoing the same amount of handling as the infected ewes.

Feeding treatments and experimental diets. From housing until $\mathrm{d}_{-28}$ all ewes were offered ad libitum hay as a sole diet in an effort to reduce $\mathrm{BCS}^{(20)}$. During late pregnancy, i.e. from $\mathrm{d}_{-28}$, all ewes were fed ad libitum the same low-protein pelleted feed until the end of the experiment. This diet was formulated to provide sufficient energy, minerals and vitamins but less than the estimated MP requirements (Table 1) of the ewes. The feed provided an estimated $7 \mathrm{~g}$ MP/MJ metabolizable energy, while the requirements for such twin-bearing/lactating ewes are estimated to be $9 \mathrm{~g}$ MP/MJ metabolizable energy ${ }^{(9,21)}$. For half of the ewes within each infection treatment this was the only food supplied (treatment: LP). The other half of the ewes in each infection treatment received, in a separate bin, an additional amount of a protein supplement (SoyPass ${ }^{\circledR}$ ) which was calculated to increase the protein supply in the total feed to around $11 \mathrm{~g}$ MP/MJ metabolizable energy (treatment: HP). To supply sufficient MP, the amount of SoyPass offered to the HP ewes was based on the intake of ewes in the study of Houdijk et al. ${ }^{(9)}$. The amounts of SoyPass offered to the $\mathrm{G}$ ewes and the smaller $\mathrm{B}$ ewes were 330 and $250 \mathrm{~g} / \mathrm{d}$ during $\mathrm{d}_{-21}$ to $\mathrm{d}_{7}$ and 450 and $340 \mathrm{~g} / \mathrm{d}$ during $\mathrm{d}_{7}$ to $\mathrm{d}_{35}$, respectively.

\section{Measurements}

Ewe and lamb performance and intake. Ewes were weighed at housing and then weekly throughout the study, as well as

Table 1. Ingredients and chemical analysis of the experimental feeds*

\begin{tabular}{|c|c|c|}
\hline & $\begin{array}{l}\text { Basal diet } \\
\text { (pelleted) }\end{array}$ & $\begin{array}{l}\text { SoyPass } \\
\text { supplement }\end{array}$ \\
\hline \multicolumn{3}{|l|}{ Ingredients (g/kg fresh feed) } \\
\hline Barley & $290 \cdot 0$ & - \\
\hline Oatfeed & $300 \cdot 0$ & - \\
\hline Citrus pulp & $300 \cdot 0$ & - \\
\hline $50 \%$ Fat premix & $17 \cdot 0$ & - \\
\hline Molasses & $50 \cdot 0$ & - \\
\hline Salt & $8 \cdot 0$ & - \\
\hline Limestone flour & 1.0 & - \\
\hline Calcined magnesite & 4.0 & - \\
\hline Dicalcium phosphate & $10 \cdot 0$ & - \\
\hline Scotmin ewe/lamb & $2 \cdot 0$ & - \\
\hline Urea & $18 \cdot 0$ & - \\
\hline $\begin{array}{l}\text { SoyPass }^{\circledR} \text { (xylose-treated } \\
\text { soyabean meal) }\end{array}$ & - & $1000 \cdot 0$ \\
\hline \multicolumn{3}{|l|}{ Analysed composition } \\
\hline$D M(g / k g$ feed) & $879 \cdot 0$ & $794 \cdot 0$ \\
\hline Crude protein (g/kg DM) & $135 \cdot 0$ & $514 \cdot 0$ \\
\hline Netural-detergent fibre (g/kg DM) & $269 \cdot 0$ & $223 \cdot 0$ \\
\hline Acid-detergent fibre (g/kg DM) & $189 \cdot 0$ & $56 \cdot 8$ \\
\hline Ether extract (g/kg DM) & $33 \cdot 3$ & $10 \cdot 8$ \\
\hline Gross energy (MJ/kg DM) & $18 \cdot 0$ & $19 \cdot 8$ \\
\hline NCGD (g/kg DM) & 734.0 & $827 \cdot 0$ \\
\hline \multicolumn{3}{|l|}{ Estimated energy and protein supply $\dagger$} \\
\hline Metabolizable protein (g/kg DM) & $73 \cdot 0$ & $400 \cdot 0$ \\
\hline Metabolizable energy (MJ/kg DM) & 10.5 & 12.5 \\
\hline
\end{tabular}

NCGD, neutral-detergent cellulase plus amylase and gamannase digestibility.

*The diets were fed from $d_{-28}$ to $d_{35}$, relative to parturition, $d_{0}$.

†According to the Agricultural and Food Research Council ${ }^{(21)}$. 
within $6 \mathrm{~h}$ after parturition. Lambs also were weighed within $6 \mathrm{~h}$ after birth and weekly thereafter. BCS estimates of ewes were first taken at housing and then weekly from $\mathrm{d}_{-42}$ onwards. BCS was measured by lumbar palpation on a scale from 0 to 5 with 0.25 increments $^{(22)}$ by the same operator. Ewe muscle and back-fat depths were measured by ultrasound scanning ${ }^{(23)}$ from $\mathrm{d}_{-42}$ onwards.

The amounts of distributed food were calculated daily to achieve ad libitum intake. Refusals were weighed twice weekly (Monday and Thursday) for calculation of average daily food intake (ADFI) and averaged $15 \%$ of the amount of food offered, which is sufficient to measure ad libitum intake $^{(24,25)}$. Experimental foods were sampled while the daily allowances were being prepared and daily samples were bulked and analysed for DM, crude protein, neutral detergent fibre and minerals. There were no refusals of the restrictedly fed SoyPass supplement through the experiment. The refusals of the pelleted food were recorded on an as fed basis, as similar refusal levels were obtained for the individual animals and there was no evidence of feed separation in the bins.

Faecal egg counts. Faecal samples were taken twice weekly directly from the rectum, from day -57 onwards and analysed for FEC according to a modified flotation method ${ }^{(26)}$. FEC was expressed as the number of eggs/g fresh faeces.

Plasma constituents. Blood samples were taken weekly from the jugular vein into heparinized vacutainers from day $\mathrm{d}_{-50}$ (pre-infection) onwards. The blood samples were centrifuged for $15 \mathrm{~min}$ at $2600 \mathrm{~g}$, and the separated plasma stored at $-20^{\circ} \mathrm{C}$ pending analysis for leptin, pepsinogen and albumin. Plasma pepsinogen was determined by the modified method of Paynter ${ }^{(27)}$ and expressed in IU (international units). Plasma albumin as an indicator of host protein nutrition was determined by a spectrophotometric method using a commercial clinical test: IL Test ${ }^{\mathrm{TM}}$ Albumin (Instrumentation Laboratory SpA, Milan, Italy) and results are reported in g/l.

\section{Leptin RIA}

PLC was determined by the use of a ruminant-specific leptin RIA as described previously by Zaralis et al. ${ }^{(28)}$. This assay uses an anti-ovine leptin antiserum raised in guinea-pigs against recombinant ovine leptin (a gift from Prof. A. Gertler, The Hebrew University of Jerusalem) at a final assay dilution of 1:160 000. Pure recombinant ovine leptin (DSL Ltd, London, UK) was used as a standard at the following concentrations: $50,25,12 \cdot 5,6 \cdot 25,3 \cdot 125,1 \cdot 56,0 \cdot 78,0 \cdot 395,0 \cdot 1975,0.098 \mathrm{ng}$ leptin/ml. Approximately $15000 \mathrm{cpm}$ of radiolabelled leptin $\left({ }^{125} \mathrm{I}\right.$-leptin), prepared by iodination with sodium $\left[{ }^{125} \mathrm{I}\right]$ iodide (Amersham, UK), was added to each tube. The tubes were incubated for $48 \mathrm{~h}$ and then bound and free ligands were separated by addition of $100 \mu \mathrm{l}$ of cellulose-bound anti-guinea-pig IgG (Sac-Cel; IDS, Washington, UK). After centrifugation $\left(3000 \mathrm{rpm} ; 4^{\circ} \mathrm{C} ; 20 \mathrm{~min}\right)$ supernatant containing unbound ${ }^{125}$ I-leptin was aspirated by vacuum pump via a trap and the residual, drained pellets were counted in a Cobra II gamma counter (Packard Canberra Ltd, UK). Six replicates of blood plasma from a fat $(\mathrm{BCS}>3.5)$ non-pregnant ewe and six from a lean $(2 \cdot 0<\mathrm{BCS}>3 \cdot 5)$ non-pregnant ewe were used as high and low leptin controls throughout each assay. The mean PLC for these high and low controls were 7.37 (SE 0.64) and $3.62(\mathrm{SE} 0.36) \mathrm{ng} / \mathrm{ml}$, respectively. The mean intra-assay CV were 9.0 and $10.2 \%$ while the inter-assay CV were 14.5 and $17.5 \%$ for high and low controls, respectively.

\section{Statistical analysis}

The data obtained for each ewe during the periparturient period were synchronized to day relative to parturition $\left(d_{0}\right)$. Mean lambing dates for $G$ and $B$ ewes were 20 April $2005 \pm 1 \mathrm{~d}$ and 27 April $2005 \pm 1 \mathrm{~d}$, respectively. The average day relative to parturition associated with data obtained during the periparturient period was computed, and used to present the results.

ADFI, BW, BCS, muscle and back-fat depths were analysed by repeated measures ANOVA with an auto-regressive correlation structure for residual errors over time, using the MIXED procedure of SAS (SAS 9.1.3; SAS Institute Inc., Cary, NC, USA). The statistical models contained the fixed effects of breed, protein supplementation, infection, time, and their interactions. In every statistical model the random effect was animal nested within breed by treatment. Data are reported as least squares means and their standard error and their differences were tested by a $t$ test.

Because ADFI and BW changed dramatically from pregnancy to lactation, data obtained during lactation and pregnancy were analysed separately and initial ewe BW difference from the mean breed $\mathrm{BW}$ measured on $\mathrm{d}_{-57}$ was used as covariable. ADFI refers to the intake of fresh basal feed only and does not include the protein supplement. Achieved MP intake $\left(\mathrm{MP}_{\mathrm{I}}\right)$ of the ewes was calculated on the basis of ADFI and the protein content of the foods. MP requirements $\left(\mathrm{MP}_{\mathrm{R}}\right)$ for pregnant and lactating ewes were estimated on the basis of maternal BW and milk yield according to recommendations of the Agricultural and Food Research Council ${ }^{(21)}$. The ratio $\mathrm{MP}_{\mathrm{I}} / \mathrm{MP}_{\mathrm{R}}$ of all ewes was subjected to statistical analysis in order to determine the degree of protein limitation or adequacy in the two breeds.

Plasma leptin data were analysed also by ANOVA using the MIXED procedure of SAS for repeated measurements. Comparison of actual plasma leptin levels between treatments was made by a model that included the main effects of breed, infection, protein supplementation, time, and their interactions (model 1). Leptin data were also analysed by a similar model that contained either the back-fat measurements or the relative food intake (RFI; $\mathrm{g} / \mathrm{kg}$ per d) of the ewes as a covariable in addition to the main effects of breed, infection, protein supplementation, time, and their interactions (model 2). The relationships between PLC and back-fat depth, and between PLC and RFI, were tested by comparing the respective covariable coefficient with its associated standard error. All models for leptin included an assay effect to take into account the between-assay variation. In every statistical model the random effect was animal nested within breed by treatment.

Lamb BW gain (g/d) was calculated by linear regression and data were analysed by ANOVA (general linear model) with the fixed effects of breed and treatment and litter sex (i.e. $q Q 9, q \sigma^{\top}$ and $\sigma^{\top} \sigma^{\top}$ litters).

FEC and pepsinogen data were log-transformed according to $\log _{10}(x+1)$, in order to normalize residuals, prior to statistical analysis. Log-transformed data were analysed by repeated measures ANOVA (GenStat Release 7.2; Lawes Agricultural Trust, Rothamsted Experimental Station, UK) as described 
earlier for the intake and performance measurements. FEC and pepsinogen data are reported as back-transformed means (according to $10^{\alpha}$, where $\left.\alpha=\mu+0.5 \times \sigma^{2}\right)^{(29)}$ with $95 \%$ CI (lower and upper limit). FEC of non-infected ewes were all zero throughout the experiment and these were, therefore, not included in the statistical analysis.

\section{Results}

The balanced structure of the experiment (eight ewes per breed per treatment) was not maintained throughout the study. One ewe had still-born lambs (treatment LP+, B), three ewes failed to adapt to the experimental feeds (one treatment $\mathrm{HP}+, \mathrm{B}$; one treatment $\mathrm{LP}-, \mathrm{B}$; and one treatment $\mathrm{LP}-, \mathrm{G}$ ) and one ewe gave birth to triplets (treatment $\mathrm{HP}-, \mathrm{G}$ ). The data obtained from these animals were excluded from the statistical analysis and treated as missing values.

\section{Faecal egg counts}

Mean back-transformed FEC for infected ewes are shown in Fig. 1. There was a significant breed effect on FEC $(P<0 \cdot 001)$ as a result of higher eggs/g fresh faeces values in $\mathrm{G}$ than in $\mathrm{B}$ ewes. Protein supplementation resulted in a significant decrease $(P=0.038)$ in FEC, but the interaction between protein supplementation and breed was not significant $(P=0 \cdot 23)$. As expected, FEC changed significantly over time $(P<0.0001)$. In all treatment groups, FEC were low until $\mathrm{d}_{-21}(<17$ eggs/g fresh faeces upper limit), increased with

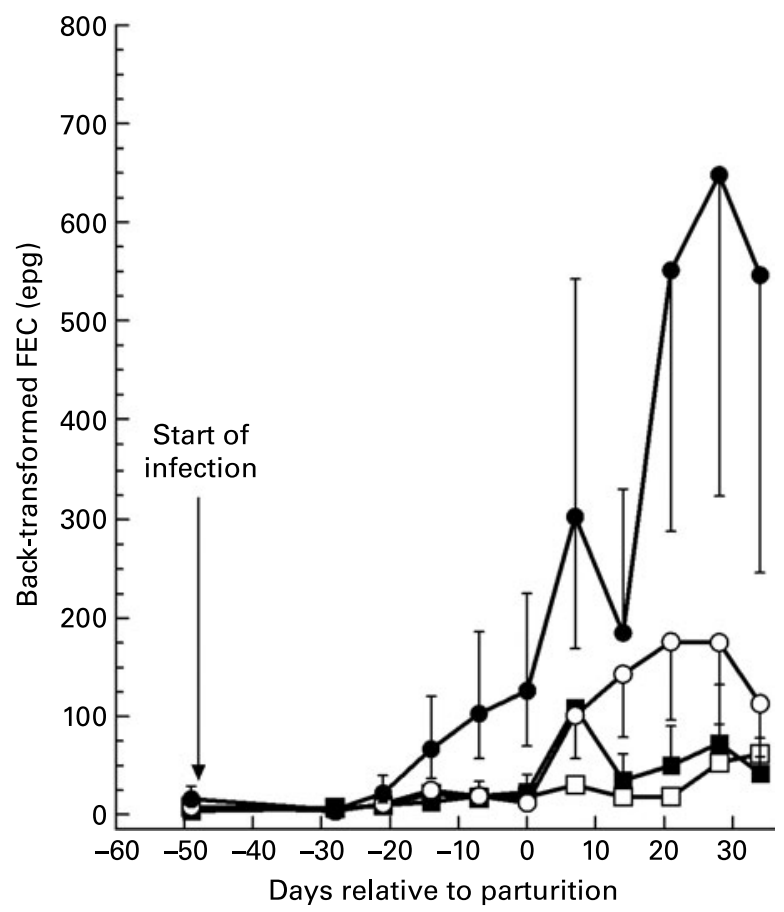

Fig. 1. Faecal egg counts (FEC; epg, number of eggs per g fresh faeces) of Greyface cross $(O, \bullet)$ and Scottish Blackface $(\square, \boldsymbol{\square})$ twin-bearing/lactating ewes, trickle infected with 30000 third-stage infective larvae of Teladorsagia circumcincta per week and offered a protein supplement $(O, \square)$ or not $(\bullet, \mathbf{\square})$ during the periparturient period $\left(d_{-28}\right.$ to $d_{33}$ of parturition $\left.\left(d_{0}\right)\right)$. The trickle infection started on $d_{-47}$. Values are back-transformed means with $95 \% \mathrm{Cl}$ depicted by vertical bars. time to peak during early lactation and then tended to decrease towards the end of the experiment. Maximum FEC for both breeds were observed on the LP treatment, i.e. on $\mathrm{d}_{7}$ for $\mathrm{B}$ ewes (119 eggs/g fresh faeces; 95\% CI 67, 213) and on $\mathrm{d}_{28}$ for $\mathrm{G}$ ewes (648 eggs/g fresh faeces; $95 \%$ CI 325, 1294). Mainly as a result of these differences, the interaction of time with breed was significant $(P=0 \cdot 005)$.

\section{Food intake}

Fig. 2 shows the observed mean ADFI of $\mathrm{G}$ and $\mathrm{B}$ ewes from $\mathrm{d}_{-24}$ until $\mathrm{d}_{31}$ of the experiment. Breeds did not differ in ADFI during late pregnancy $\left(\mathrm{d}_{-24}\right.$ to $\left.\mathrm{d}_{0} ; P=0.53\right)$ or lactation $\left(\mathrm{d}_{0}\right.$ to $\left.\mathrm{d}_{31} ; P=0.85\right)$. ADFI in both breeds did not change with time during late pregnancy $(P=0.09)$ but increased significantly
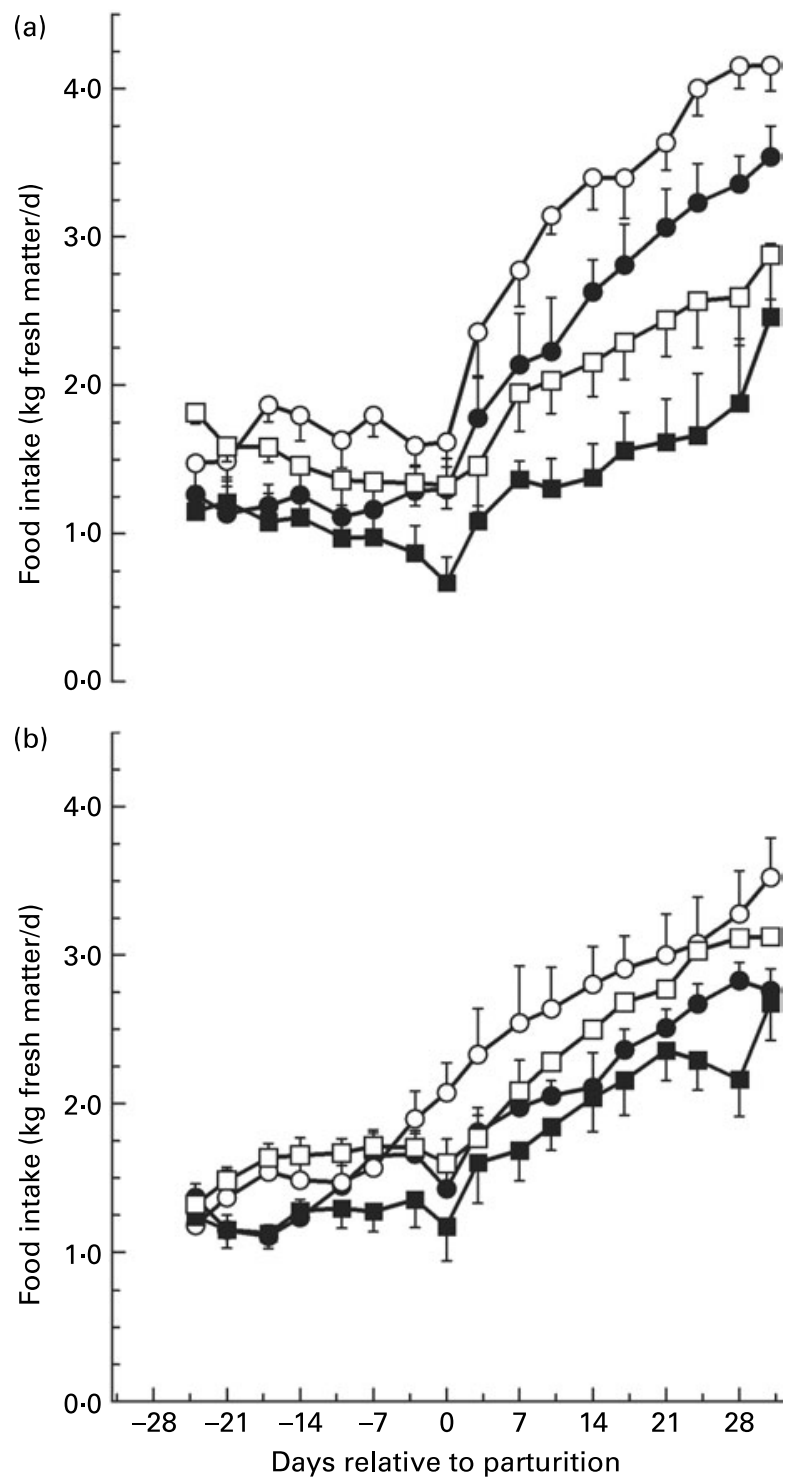

Fig. 2. Average daily food intake of Greyface cross (a) and Scottish Blackface (b) twin-bearing/lactating ewes, trickle infected with 30000 third-stage infective larvae of Teladorsagia circumcincta per week $(\bullet, \mathbf{0})$ or non-infected $(\bigcirc$, $\square)$ and offered a protein supplement $(\bigcirc, \bullet)$ or not $(\square, \boldsymbol{\square})$ during the periparturient period $\left(d_{-28}\right.$ to $d_{33}$ of parturition $\left.\left(d_{0}\right)\right)$. The trickle infection started on $d_{-47}$. Values are group means with their standard errors depicted by vertical bars. 
during lactation in both breeds $(P<0 \cdot 001)$. Nematode infection resulted in a significant reduction in ADFI in both breeds during late pregnancy (reduction around 12\%; $P=0.026$ ) and even more so during lactation (reduction around 22\%;P=0.0036). Interactions between breed and infection were not significant in either period $(P>0 \cdot 5)$. Protein supplementation resulted in higher ADFI in $G$ ewes but not in $\mathrm{B}$ ewes especially during lactation as indicated by the significant interaction between breed and protein supplementation $(P=0.011$; see also Fig. 2 and Table 2$)$. The interaction between protein supplementation and infection was not significant during either late pregnancy $(P=0.58)$ or lactation $(P=0 \cdot 86)$, which showed that protein supplementation did not affect the extent of the observed anorexia.

Protein supplementation resulted in MP intakes that were higher than the estimated MP requirements, during both late pregnancy and lactation in both breeds (Table 2). Ewes that were fed the low-protein basal diet only had a ratio of MP intake to $\mathrm{MP}$ requirements $\left(\mathrm{MP}_{\mathrm{I}}: \mathrm{MP}_{\mathrm{R}}\right)$ below 1 . This ratio was much lower for $\mathrm{G}$ ewes than for $\mathrm{B}$ ewes, which resulted in a significant interaction between the effects of protein and breed during both late pregnancy and lactation (Table 2).

\section{Ewe and lamb performance}

During both periods, $G$ ewes were heavier than $B$ ewes $(P<0.0001$; see Fig. 3). Infected ewes in both breeds had lower $\mathrm{BW}$ than non-infected ewes during both late pregnancy $(P=0.003)$ and lactation $(P=0.0002)$. A difference in ewe BW between HP and LP treatments was observed only in G ewes and this was reflected by a significant interaction between breed and protein supplementation during both late pregnancy $(P=0.04)$ and lactation $(P=0.01$; see Fig. 3$)$. There was also a significant interaction between breed and time on ewe BW because $\mathrm{B}$ ewes gained more $\mathrm{BW}$ than $\mathrm{G}$ ewes, but this was apparent only during lactation $(P=0.003)$. G ewes lost more BCS over time than $\mathrm{B}$ ewes did as indicated by a significant interaction between breed and time $(P<0.0001)$. On average, infected ewes had lower BCS compared to non-infected ewes as shown by the main effect of infection $(P=0 \cdot 016$; Table 3$)$ but the infection by time interaction was not statistically significant $(P=0 \cdot 22)$. Unsupplemented ewes lost more BCS compared to protein-supplemented ewes over time as shown by the interaction between protein supplementation and time $(P=0.0003)$.

At lambing, mean whole-litter BW of $\mathrm{G}$ and $\mathrm{B}$ ewes were 10.6 (SE 0.26) and $6.6($ SE 0.26$) \mathrm{kg}(P<0.0001)$. Mean daily litter BW gains were 559 (SE 29) and 419 (SE 27) g/d for G and $\mathrm{B}$ ewes, respectively $(P=0 \cdot 001)$. Litter sex tended to affect litter birth weight with $\$ Q q, q \sigma^{\top}$ and $\sigma^{\top} \sigma^{\top}$ litter mean weights of $9.9,10.9$ and $10.8 \mathrm{~kg}$ in $\mathrm{G}$ ewes and 5.9 , 7.0 and $6.9 \mathrm{~kg}$ in $\mathrm{B}$ ewes (SE $0.4, P=0.07$ ). Across treatments, HP ewes produced heavier litters than LP ewes $(P=0.03)$ but there were no differences in birth weights between litters produced by infected and non-infected ewes $(P=0 \cdot 3)$. There was a significant breed $\times$ protein supplementation interaction due to the faster growth of the G lambs from the HP treatment $(P=0 \cdot 006)$. Litters nursed by infected ewes tended to have lower whole-litter BW gain $(P=0 \cdot 1)$ than litters nursed by non-infected ewes but the interaction between breed and infection on whole-litter weight gain was not significant $(P=0 \cdot 8)$.

\section{Back-fat and muscle depth}

Mean back-fat depth was considerably higher in $G$ ewes $(4 \cdot 3$, SE $0.11 \mathrm{~mm})$ than in $\mathrm{B}$ ewes $(2.0(\mathrm{SE} 0 \cdot 11) \mathrm{mm})$ during the periparturient period $(P<0 \cdot 0001)$ but because $\mathrm{G}$ ewes lost more BCS than B ewes the interaction between breed and time was significant $(P<0.0001 ;$ Fig. 4). Back-fat depth was affected positively by protein supplementation over time $(P=0.04)$ and negatively by infection $(P=0.05)$ in both breeds.

In ewes of both breeds, muscle depth decreased during late pregnancy $(P<0 \cdot 001)$. During lactation, muscle depth remained almost static in $G$ ewes but increased in B ewes; that was reflected by a significant breed $\times$ time interaction $(P<0 \cdot 001)$. Infected ewes had significantly lower muscle depth compared to non-infected ewes in both breeds

Table 2. Achieved average daily fresh food intake from basal diet $(\mathrm{kg})$ and total metabolizable protein $(\mathrm{MP} ; \mathrm{g})$ intakes of twin-bearing/lactating ewes that received (HP) or did not receive (LP) a protein supplement and were infected $(+)$ or not infected $(-)$ with the nematode Teladosargia circumcincta†

\begin{tabular}{|c|c|c|c|c|c|c|c|c|c|c|}
\hline \multirow[b]{2}{*}{ Item } & \multicolumn{4}{|c|}{ Greyface cross } & \multicolumn{4}{|c|}{ Scottish Blackface } & \multirow[b]{2}{*}{ SE‡ } & \multirow[b]{2}{*}{ Response } \\
\hline & $\mathrm{HP}-$ & $\mathrm{HP}+$ & LP- & $\mathrm{LP}+$ & $\mathrm{HP}-$ & $\mathrm{HP}+$ & LP- & $\mathrm{LP}+$ & & \\
\hline \multicolumn{11}{|c|}{ Pregnancy (days -24 to 0 ) } \\
\hline Intake (kg fresh) & 1.6 & 1.2 & 1.5 & $1 \cdot 1$ & 1.4 & 1.3 & 1.6 & $1 \cdot 2$ & 0.1 & $\left.\right|^{\star \star \star}$ \\
\hline$M P_{1}(g)$ & $211 \cdot 0$ & $181 \cdot 0$ & 94.0 & $67 \cdot 0$ & $169 \cdot 0$ & $165 \cdot 0$ & $102 \cdot 0$ & $77 \cdot 0$ & $7 \cdot 8$ & $P^{\star \star \star}, I^{\star \star \star}, B \times P^{\star \star \star}$ \\
\hline $\mathrm{MP}_{\mathrm{I}}: \mathrm{MP}_{\mathrm{R}} \S$ & 1.48 & 1.28 & 0.66 & 0.47 & 1.31 & 1.28 & 0.79 & 0.6 & 0.06 & $\mathrm{P}^{\star * *}, \mathrm{I}^{\star * *}, \mathrm{~B} \times \mathrm{P}^{*}$ \\
\hline \multicolumn{11}{|c|}{ Lactation (days 0 to 35 ) } \\
\hline Intake (kg fresh) & $3 \cdot 1$ & $2 \cdot 3$ & $2 \cdot 1$ & 1.7 & $2 \cdot 7$ & $2 \cdot 1$ & $2 \cdot 4$ & $1 \cdot 8$ & 0.25 & $\mathrm{P}^{\star \star \star}, \mathrm{I}^{\star \star \star}, \mathrm{B} \times \mathrm{P}^{*}$ \\
\hline$M P_{1}(g)$ & 339.0 & $290 \cdot 0$ & $142 \cdot 0$ & $104 \cdot 0$ & $281 \cdot 0$ & $243 \cdot 0$ & $153 \cdot 0$ & $114 \cdot 0$ & $16 \cdot 4$ & $\mathrm{P}^{\star \star \star}, \mathrm{I}^{\star \star \star}, \mathrm{B} \times \mathrm{P}^{\star \star \star *}$ \\
\hline $\mathrm{MP}_{\mathrm{I}}: \mathrm{MP}_{\mathrm{R}} \S$ & 1.37 & $1 \cdot 17$ & 0.57 & 0.43 & 1.38 & 1.2 & 0.75 & 0.56 & 0.07 & $\mathrm{~B}^{\star}, \mathrm{P}^{\star \star \star}, \mathrm{I}^{\star \star \star}, \mathrm{B} \times \mathrm{P}^{\star}$ \\
\hline
\end{tabular}

$M P_{1}, M P$ intake; $M_{R}$, MP requirement.

Values were significantly different: ${ }^{\star} P<0.05,{ }^{* \star} P<0.01,{ }^{\star \star \star} P<0.001$ (B, breed (Greyface cross $v$. Scottish Blackface); I, infection (+ v. - ); P, protein supplementation (HP $v$. LP)). $\dagger$ For details of procedures and chemical analysis, see the Materials and methods section and Table 1 . Infection started on $d_{-47}$ relative to parturition $\left(d_{0}\right)$ and animals were receiving orally 30000 third-stage infective larvae per week. Non-infected animals were receiving only water ('sham' infected). Protein supplementation started on $d_{-28}$. The protein supplement was SoyPass ${ }^{\circledR}$ (xylose-treated soyabean meal).

$\ddagger$ Based on error mean squares pooled over treatment groups.

$\S$ Estimated $\mathrm{MP}_{\mathrm{R}}$ for twin-bearing ewes based on maternal body weight were 142 and $129 \mathrm{~g}$ for Greyface cross and Scottish Blackface ewes, respectively. Estimated $\mathrm{MP}$ for lactating ewes based on maternal body weight and assuming milk yield of 3 and $2 \mathrm{~kg} / \mathrm{d}$ were 248 and $203 \mathrm{~g}$ for Greyface cross and Scottish Blackface ewes, respectively (according to the Agricultural and Food Research Council ${ }^{(21)}$ ). 

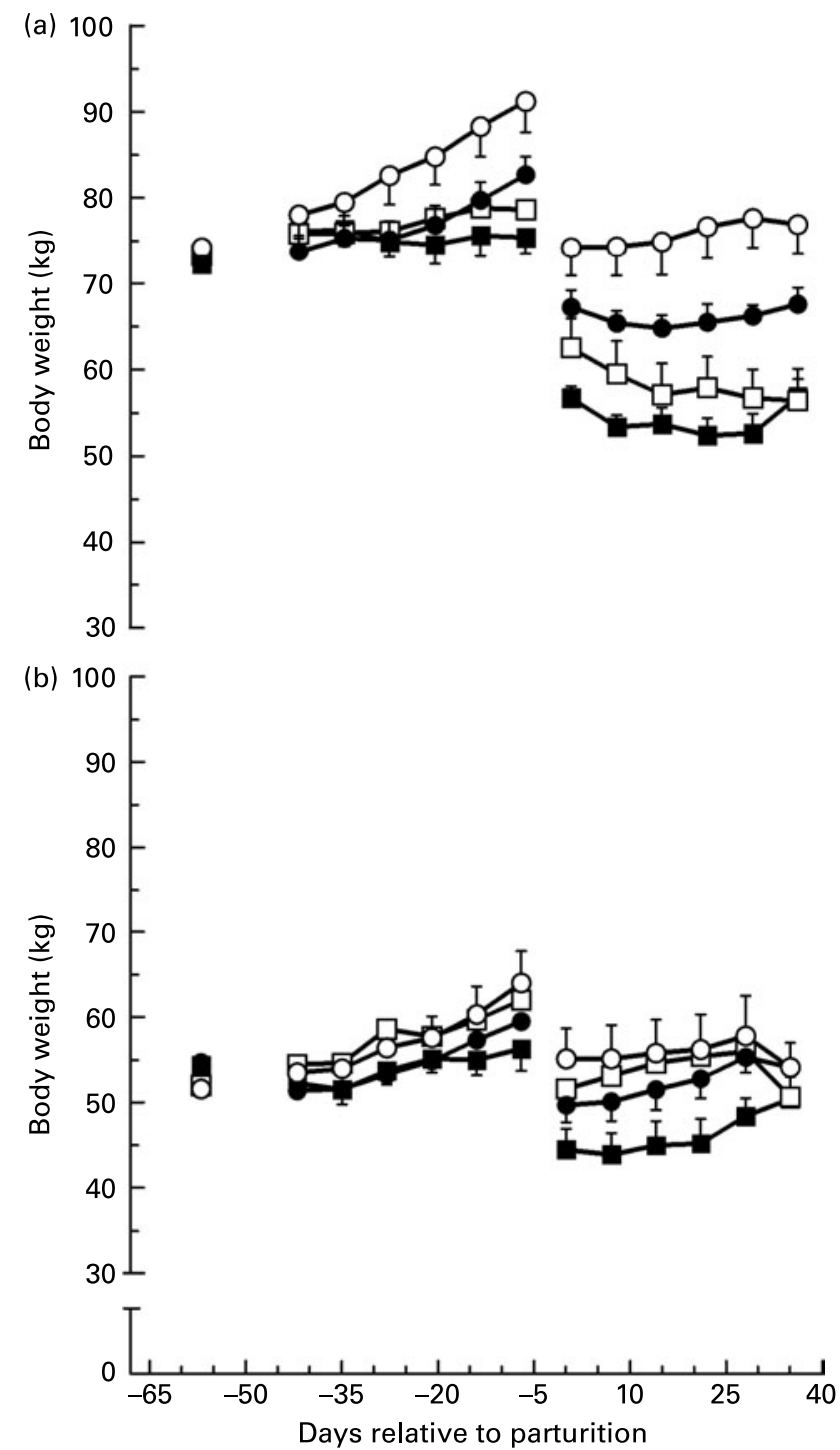

Fig. 3. Weekly body weight of Greyface cross (a) and Scottish Blackface (b) twin-bearing/lactating ewes, trickle infected with 30000 third-stage infective larvae of Teladorsagia circumcincta per week $(\boldsymbol{\bullet}, \mathbf{\square})$ or non-infected $(\bigcirc, \square)$ and offered a protein supplement $(\bigcirc, \bullet)$ or not $(\square, \boldsymbol{\square})$ during the periparturient period $\left(d_{-28}\right.$ to $d_{33}$ of parturition $\left.\left(d_{0}\right)\right)$. The trickle infection started on $d_{-47}$. Values are group means with their standard errors depicted by vertical bars.

$(P=0.02$; Table 3$)$. Protein supplementation did not affect muscle depth in $B$ ewes but it had a positive effect in $G$ ewes as shown by a statistically significant interaction between breed and protein supplementation $(P=0.03$; Table 3$)$.

\section{Plasma constituents}

Plasma pepsinogen. Plasma pepsinogen concentrations were similar in non-infected ewes of both breeds, were not affected by protein supplementation and did not change systematically with time (Fig. 5). Infected ewes had higher plasma pepsinogen concentrations than non-infected ewes and differences were significant from the first week of infection in both breeds $(P<0 \cdot 0001)$. Protein supplementation had no effect on pepsinogen concentrations in $\mathrm{B}$ ewes but it resulted in a decrease in plasma pepsinogen concentration in $G$ ewes from parturition until the fourth week of lactation; this was reflected by significant breed $\times$ protein supplementation interaction $(P=0 \cdot 017)$.

Plasma albumin. Plasma albumin concentrations across treatments were 32.6 and 31.1 (SE 0.8) $\mathrm{g} / \mathrm{l}$ for $\mathrm{G}$ and $\mathrm{B}$ ewes, respectively. Plasma albumin concentrations increased from late pregnancy to lactation in both breeds $(P<0 \cdot 0001)$. Ewes on the LP treatment had significantly lower plasma albumin concentrations compared to ewes on the HP treatment $(P=0.0002)$ and these differences were more pronounced during lactation. The breed by protein supplementation interaction was not significant $(P=0 \cdot 65)$. Infection resulted in significantly lower plasma albumin concentrations in both HP- and LP-treated ewes of both breeds $(P=0 \cdot 02)$.

Plasma leptin. Analysis of PLC with model 1 (no covariables included) showed no effect of infection $(P=0.77)$ or of protein supplementation $(P=0.52)$ but PLC was higher $(P=0.005)$ in $\mathrm{G}(1.2(\mathrm{SE} 0.11) \mathrm{ng} / \mathrm{ml})$ than in B ewes $(0.7$ (SE $0 \cdot 11) \mathrm{ng} / \mathrm{ml}$ ). However, the breed difference in PLC disappeared $(P=0.43)$ when data were analysed with model 2 , in which, back-fat depth was included as a covariable. This model showed that there was a statistically significant $(P<0 \cdot 001)$ positive relationship between PLC and back-fat depth, as evidenced by the covariable coefficient and the interaction between breed and back-fat depth was found to be statistically non-significant $(P=0.22)$. The estimated covariable coefficient showed that a difference in back-fat depth of $1 \mathrm{~mm}$ was associated with a difference in PLC of 0.184 (SE 0.028) ng/ml ( $P<0 \cdot 001)$. According to this model PLC was also not affected by infection $(P=0.87)$ or protein supplementation $(P=0.54)$. The model that included RFI as a covariable showed that there was no statistical evidence of a relationship between PLC and RFI $(P=0.27)$ but the breed effect remained significant $(P=0.005)$. All models showed that PLC was affected by time $(P<0.001)$, mainly because of the gradual increase in PLC after parturition.

Table 3. Average body condition score (BCS) and muscle depth (MD) of twin-bearing/lactating ewes that received (HP) or did not receive (LP) a protein supplement and were infected $(+)$ or not infected $(-)$ with the nematode Teladosargia circumcincta†

\begin{tabular}{|c|c|c|c|c|c|c|c|c|c|c|}
\hline \multirow[b]{2}{*}{ Item } & \multicolumn{4}{|c|}{ Greyface cross } & \multicolumn{4}{|c|}{ Scottish Blackface } & \multirow[b]{2}{*}{ SE‡ } & \multirow[b]{2}{*}{ Response } \\
\hline & $\mathrm{HP}-$ & $\mathrm{HP}+$ & LP- & $\mathrm{LP}+$ & $\mathrm{HP}-$ & $\mathrm{HP}+$ & LP- & LP+ & & \\
\hline BCS & $2 \cdot 9$ & $2 \cdot 7$ & $2 \cdot 7$ & $2 \cdot 5$ & $2 \cdot 4$ & $2 \cdot 4$ & $2 \cdot 4$ & $2 \cdot 2$ & 0.08 & $\mathrm{~B}^{\star \star \star}, \mathrm{P}^{\star \star \star}, \mathrm{I}^{\star \star}$ \\
\hline MD & 23.9 & $22 \cdot 9$ & $21 \cdot 7$ & $20 \cdot 7$ & $21 \cdot 2$ & $20 \cdot 1$ & $20 \cdot 3$ & $19 \cdot 8$ & 0.50 & $B^{\star \star \star}, P^{\star \star \star}, I^{\star \star}, B \times P^{\star \star}$ \\
\hline
\end{tabular}

Values were significantly different: ${ }^{\star} P<0.05,{ }^{\star \star} P<0.01$, ${ }^{\star \star \star} P<0.001$ (B, breed (Greyface cross $v$. Scottish Blackface); I, infection (+ $v$. - ); P, protein supplementation (HP $v$. LP)). $\dagger$ For details of procedures and chemical analysis, see Materials and methods section and Table 1 . Infection started on $\mathrm{d}_{-47}$ relative to parturition ( $\left.\mathrm{d}_{0}\right)$ and animals were receiving orally 30000 third-stage infective larvae per week. Non-infected animals were receiving only water ('sham' infected). Protein supplementation started on $\mathrm{d}_{-28}$. BCS and MD were measured weekly from $d_{-42}$ to $d_{30}$. The protein supplement was SoyPass ${ }^{\circledR}$ (xylose-treated soyabean meal).

$\ddagger$ Based on error mean squares pooled over treatment groups. 

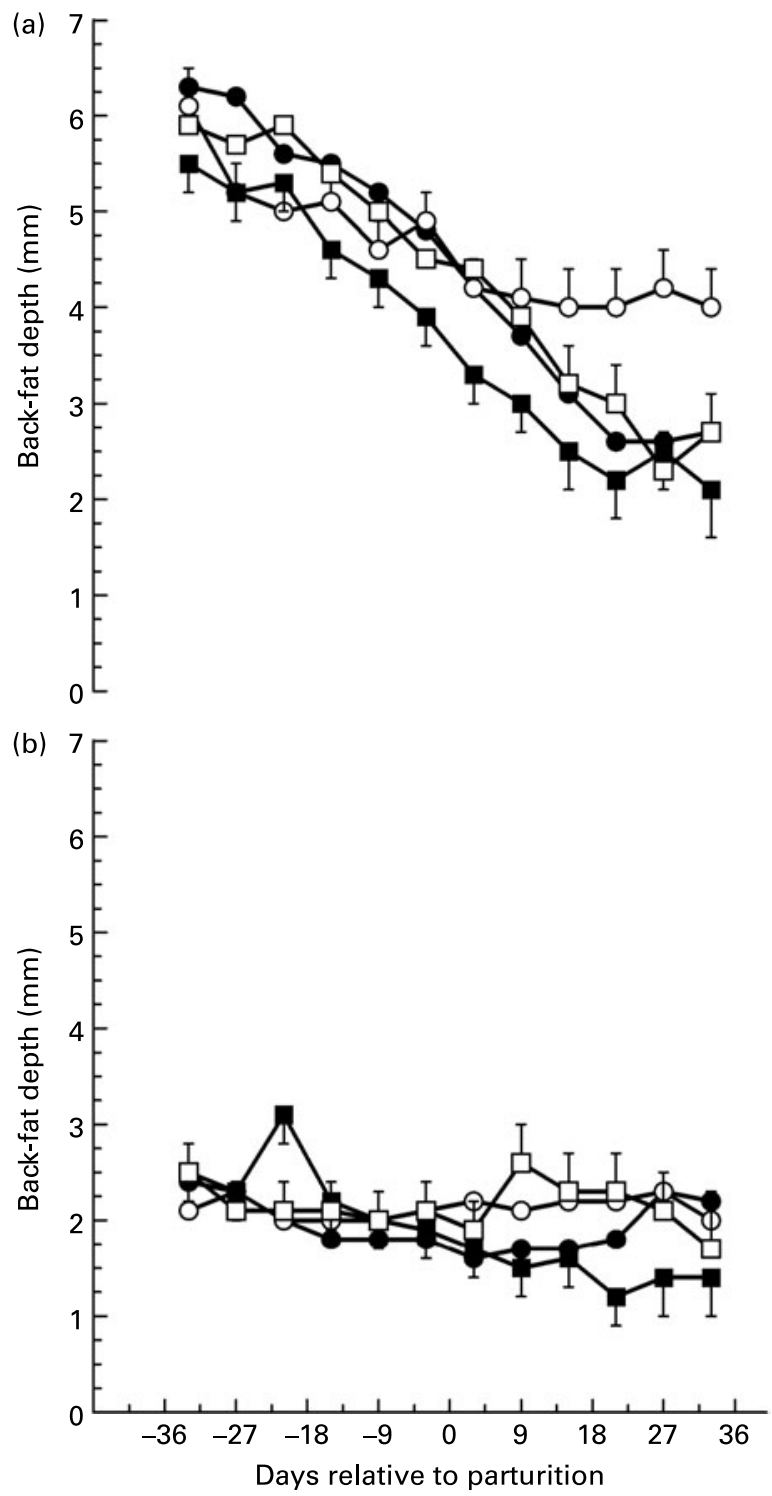

Fig. 4. Weekly back-fat depth of Greyface cross (a) and Scottish Blackface (b) twin-bearing/lactating ewes, trickle infected with 30000 third-stage infective larvae of Teladorsagia circumcincta per week $(\boldsymbol{\bullet}, \mathbf{\square})$ or non-infected $(O, \square)$ and offered a protein supplement $(\mathrm{O}, \bullet)$ or not $(\square, \square)$ during the periparturient period $\left(d_{-28}\right.$ to $d_{33}$ of parturition $\left.\left(d_{0}\right)\right)$. The trickle infection started on $d_{-47}$. Values are group means with their standard errors depicted by vertical bars.

\section{Discussion}

A T. circumcincta challenge was imposed upon half of the experimental periparturient ewes of two different breeds which did or did not receive a protein supplement to evaluate the effects of infection, breed and protein supplementation on parasiteinduced anorexia and PLC. The effects of breed and protein supplementation on PPRI will be considered before we discuss the results in relation to the hypotheses developed in the introduction.

\section{Effects of breed and protein supplementation on periparturient relaxation of immunity}

Periparturient ewes displayed a loss of their acquired immunity to $T$. circumcincta infection as evidenced by an increase
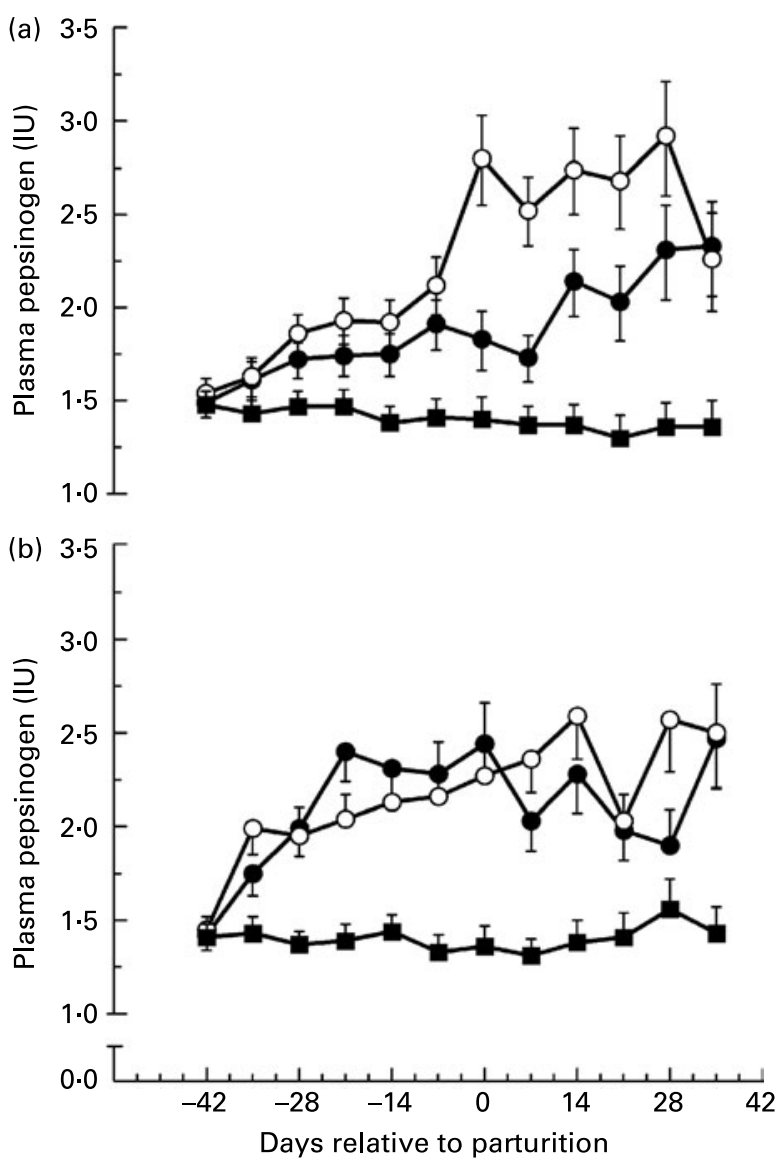

Fig. 5. Pepsinogen concentrations of Greyface cross (a) and Scottish Blackface (b) twin-bearing/lactating ewes, trickle infected with 30000 third-stage infective larvae of Teladorsagia circumcincta per week and offered a protein supplement $(O)$ or not $(\bullet)$ during the periparturient period $\left(d_{-28}\right.$ to $d_{33}$ of parturition $\left(\mathrm{d}_{0}\right)$ ). The trickle infection started on $\mathrm{d}_{-47}$. Data from non-infected ewes are also shown $(\boldsymbol{\square})$ and were averaged across the nutritional treatments. Values are back-transformed means with $95 \% \mathrm{Cl}$ depicted by vertical bars.

in FEC during late pregnancy and lactation. FEC as an indirect measure of immunity has proven to be an effective criterion with which to assess the extent of PPRI in ewes and it has frequently been used to compare differences in resistance to infection between breeds ${ }^{(4,5,10,30-33)}$. In the LP treatment, infected $\mathrm{G}$ ewes had FEC which were more than five times higher than that of B ewes (Fig. 1). In addition, the relaxation of immunity occurred earlier in $G$ ewes compared to B ewes as indicated by the significant rise in FEC during late pregnancy (Fig. 1). Significant differences in the extent and timing of PPRI between the two breeds suggest that B ewes were more resistant to $T$. circumcincta infection than $G$ ewes under the same plane of nutrition.

In agreement with previous studies ${ }^{(8,9)}$, protein supplementation in $\mathrm{G}$ ewes limited the extent of PPRI during late pregnancy as evidenced by the significantly lower FEC during lactation $\left(\mathrm{d}_{7}\right.$ onwards; Fig. 1$)$. In $\mathrm{B}$ ewes, with the exception of the first week of lactation, the differences in FEC between $\mathrm{HP}$ and LP treatments were not as large as they were in G ewes (Fig. 1). Protein supplementation resulted also in lower pepsinogen levels, an indicator of mucosal damage by the parasite, in $\mathrm{G}$ ewes during lactation but it did not affect pepsinogen levels in B ewes (Fig. 5). 
The finding that the two breeds differed significantly in their resistance to infection could be due to the enhanced genetic resistance of the $\mathrm{B}$ breed per se. However, the nutrient partitioning framework of Coop \& Kyriazakis $^{(7)}$ suggests that the degree of nutrient scarcity can affect the degree of breakdown of immunity to parasites. Several studies with ewes ${ }^{(8,9,34)}$, goats ${ }^{(35)}$ and more recently with rats ${ }^{(36)}$ have shown that dietary MP scarcity exaggerates the extent of PPRI while an increased supply of, or a decreased demand for, MP reduces PPRI. Based on their own ad libitum food intake, unsupplemented $G$ ewes achieved a lower proportion of their MP requirements than unsupplemented B ewes, as discussed later. This in itself could be sufficient explanation for the differences in PPRI observed between the two breeds. Whether B ewes would have displayed the same degree in PPRI as G ewes if they had been fed to the same degree of MP scarcity remains to be investigated.

\section{Effects of breed and infection on food intake}

Although the effects of gastrointestinal infection on sheep immune response has been studied extensively ${ }^{(4)}$, our knowledge of the effects of nematode infection on food intake changes in periparturient ewes is limited. The only investigation of effects of nematode infection on ADFI in periparturient ewes is from Leyva et al. ${ }^{(6)}$ and their study reported a reduction in food intake. Nematode-infected barren ewes that maintain their acquired immunity to nematodes do not show a reduction in food intake ${ }^{(37)}$. This suggests that in periparturient ewes the occurrence of anorexia is related to the relaxation of immunity.

The results show that infected ewes had significantly lower food intake than non-infected ewes during the periparturient period. However, the degree of anorexia was not strongly associated with the differences in the extent of the PPRI between the high and the lower production potential breed. Therefore, the results of the present study do not support the hypothesis that anorexia is greater in ewes selected more intensively for high productivity than in ewes that have been selected less intensively. Leyva et al. ${ }^{(6)}$ reported a $16 \%$ reduction in food intake during lactation in parasitized Poll Dorset ewes fed on a good quality diet (145 g crude protein/ $\mathrm{kg}$ DM), but they did not observe any reduction in food intake during late pregnancy. The present findings that infected ewes experienced a reduction in food intake during late pregnancy (around 12\%) as well as during lactation (around $22 \%$ ) show that anorexia in periparturient ewes can occur before any increase in FEC is observed.

Leyva et al. ${ }^{(6)}$ supported the view that the occurrence of anorexia in periparturient ewes is unlikely to be attributable to abomasal damage, as suggested by Sykes \& Coop $^{(38)}$ based on an experiment with parasitized lambs. Although the mechanisms underlying the parasite-induced anorexia in sheep remain unclear, a recent study has shown that the occurrence of anorexia in parasitized sheep is associated with the development (acquisition) of the immune response rather than the expression of immunity per se ${ }^{(37)}$. Immune response was not dependent on IgA production and was not accompanied by a reduction in food intake in non-pregnant or non-lactating ewes ${ }^{(37)}$. Nevertheless, a significant increase in $\operatorname{IgA}$ levels is closely associated with the rise in FEC in periparturient ewes ${ }^{(39,40)}$ but also in infected parasite-naïve lambs ${ }^{(41)}$. Greer et al. ${ }^{(37)}$ suggested that the physiological changes associated with the acquisition phase of the immune response, characterized by the stimulation of IgA production, are responsible for the loss in appetite in infected parasite-naïve lambs. Because mature animals restore their immune response following the PPRI, it is possible that the parasite-induced anorexia in periparturient ewes is related to the developing immune responses which eventually lead to the restoration of immunity.

\section{Effects of protein supplementation on food intake and performance}

The extent of PPRI in ewes is sensitive to dietary protein intake ${ }^{(8,34)}$. For that reason we also investigated how protein supplementation affected the degree of anorexia in periparturient ewes. $\mathrm{G}$ ewes were heavier and lambs nursed by $\mathrm{G}$ ewes had significantly higher BW and weight gain than lambs nursed by $B$ ewes (Fig. 3). These differences imply that $G$ ewes had a greater MP demand for maintenance, late pregnancy and lactation than $\mathrm{B}$ ewes ${ }^{(21,42)}$, supporting the rationale for feeding a higher protein supplement to $\mathrm{G}$ ewes on the HP treatment. However, in order to be able to measure anorexia as a result of infection, all ewes were fed ad libitum. G ewes on the HP treatments did indeed consume more basal diet than B ewes and all HP groups achieved an MP intake that was more than adequate in relation to their requirements, as intended.

Unexpectedly, LP ewes of both breeds consumed similar amounts of basal diet, which resulted in $\mathrm{G}$ ewes consuming a lower proportion of their MP requirements than B ewes during late pregnancy and during lactation (see Table 2). Therefore, over the entire periparturient period, MP supply was more limiting in $\mathrm{G}$ ewes than in B ewes. Since the Agricultural and Food Research Council ${ }^{(21)}$ system does not take into account effects of urea recycling on MP scarcity, it seems likely that MP supply on the LP treatment was underestimated $^{(43)}$. Performance of $\mathrm{B}$ ewes and their lambs was similar in supplemented and unsupplemented treatments, suggesting that the MP limitation must have been small. In contrast, unsupplemented $\mathrm{G}$ ewes lost more weight (Fig. 3) and their lambs gained less weight than their counterparts in the supplemented treatments. The present observations agree with the MP supply data that the MP limitation was much more severe in $\mathrm{G}$ than in $\mathrm{B}$ ewes.

Protein supplementation had no significant effect on the degree of anorexia in either breed because the reduction in ADFI was similar in the HP and LP treatments. The present finding does, therefore, not support the hypothesis that protein supplementation can lower the extent of anorexia in a manner similar to its effect on PPRI. In the only other study that investigated effects of food quality on anorexia, the degree of anorexia following trypanosome infection was also similar in goats that received either a high- or a low-protein food ${ }^{(44)}$. We conclude that protein supplementation affected PPRI as measured by FEC but not anorexia and that the latter two variables are, therefore, not strongly related.

The significant interactions between breed and protein supplementation on ewe BW and whole-litter BW provide indirect evidence of differences between breeds in the extent to which their protein demands were met. However, the present results may not have been the exclusive effect of differences in protein 
scarcity because they could well have been affected by the differences in total ADFI between G ewes on the HP and LP treatments. The differences between breeds in protein scarcity as a result of the LP treatment were, to some extent, also reflected in the lower muscle depth in $G$ ewes, but not in $B$ ewes, when compared to their HP counterparts, since it has been shown that MP undernutrition reduces the weights of a range of proteinaceous body components ${ }^{(45,46)}$. In addition, excess MP can improve abomasal integrity restoration which in turn leads to lower plasma pepsinogen concentrations in infected ewes ${ }^{(19)}$. Accordingly, the absence of a significant effect of protein supplementation on pepsinogen concentrations in $B$ ewes, in contrast to $G$ ewes, could also be a reflection of the differences in protein scarcity between the two breeds.

\section{Effects of infection on plasma leptin concentration in relation to back-fat reserves}

An important role in the relationship between nutritional status and immune function has been recently ascribed to leptin ${ }^{(47)}$. Changes in PLC in response to inflammation have been suggested to be important for the animals' ability to cope with, and survive, infections ${ }^{(48)}$. Therefore, we tested the hypothesis that nematode infection of periparturient ewes will result in increased PLC.

Data obtained in a recent study ${ }^{(18)}$ suggested that differences in the immune response appeared to be associated with differences in serum leptin levels in periparturient ewes infected with Haemonchus contortus. Although the study was the first to address the possible implication of leptin during the periparturient immune response in ewes, the results were difficult to interpret because of the absence of any noninfected control ewes in that experiment. The experimental design of the present study allowed a direct comparison of PLC between infected and non-infected ewes during the periparturient period. Since a positive relationship between adiposity and PLC exists in ruminants ${ }^{(49,50)}$, the statistical model for PLC analysis included body fat depth as covariable to take this into account. The present results showed that PLC was affected significantly by time. The results are in accordance with the finding that maternal PLC in ewes declines from mid-pregnancy to early lactation where it reaches a nadir and increases gradually thereafter ${ }^{(13)}$. The present results also show that PLC was positively correlated with back-fat depth, which is consistent with previous observations. Infected ewes tended to have lower back-fat depth and significantly lower BCS. However, when differences in back-fat reserves were accounted for, infected ewes did not differ in their PLC from non-infected ewes, which suggests that PLC are unlikely to be increased as a result of infection in periparturient ewes. In addition, despite protein supplementation that resulted in increased albumin and lower pepsinogen levels and reduced the extent of PPRI in periparturient ewes, PLC was not significantly affected by the level of protein supplementation. This further suggests that PLC are unlikely to be involved in MP partitioning towards the physiological functions of the host. Reduced appetite in ruminants has previously been ascribed primarily to physical limitations of the gastrointestinal tract, but metabolic signals may play an equally important role ${ }^{(51,52)}$. Although a role for leptin for the anorexia of infection has been proposed in other models of disease $^{(16,17)}$, the present results suggest that leptin is unlikely to contribute to the reduction in appetite in infected periparturient ewes because PLC did not differ between infected and control ewes and PLC was not strongly associated with RFI.

\section{Conclusions}

The present study showed that $T$. circumcincta infection resulted in anorexia in periparturient ewes of each of two breeds differing in production potential, and that the anorexia can occur before any increase in FEC is observed. The differential breed responses to nematode infection were not associated with breed differences in anorexia. The results add to the growing body of evidence that where breakdown of immunity to $T$. circumcincta infection occurs under conditions of protein scarcity, the supplementation with protein can lower the extent of the breakdown. However, the hypothesis that dietary protein supplementation can reduce the magnitude of anorexia in periparturient ewes had to be rejected. The results were also not consistent with the hypothesis that nematode infection of periparturient ewes would result in increased PLC and it is unlikely that leptin is involved in the occurrence of anorexia of nematode-infected periparturient ewes.

\section{Acknowledgements}

We wish to thank Lesley Deans, Dave Anderson and Terry McHale for care of the animals, data collection and parasitological technical support and Emmanuel McAughey for assistance with leptin immunoassays. We are also grateful to the Scottish Government for financial support, to Mitch Lewis and Colin Morgan for advice on diet formulation and to Ian Nevison of BioSS for statistical advice. K. Z. is grateful to the Hellenic State Scholarship Foundation for the provision of a postgraduate scholarship. None of the authors has a conflict of interest in relation to this study. This paper has resulted from the postgraduate studies of $\mathrm{K}$. $\mathrm{Z}$. and is part of his $\mathrm{PhD}$ thesis. All other authors have contributed equally to the paper.

\section{References}

1. Coop RL, Sykes AR \& Angus KW (1982) The effect of 3 levels of intake of ostertagia-circumcincta larvae on growth-rate, foodintake and body-composition of growing lambs. J Agric Sci 98, $247-255$

2. Kyriazakis I, Anderson DH, Coop RL \& Jackson F (1996) The pathophysiology and development of immunity during longterm subclinical infection with Trichostrongylus colubriformis of sheep receiving different nutritional treatments. Vet Parasitol 65, 41-54.

3. Kimambo AE, Macrae JC, Walker A, Watt CF \& Coop RL (1988) Effect of prolonged subclinical infection with Trichostrongylus-colubriformis on the performance and nitrogenmetabolism of growing lambs. Vet Parasitol 28, 191-203.

4. Barger IA (1993) Influence of sex and reproductive status on susceptibility of ruminants to nematode parasitism. Int J Parasitol 23, 463-469.

5. Donald AD, Morley FHW, Waller PJ, Axelsen A, Dobson RJ \& Donnelly JR (1982) Effects of reproduction, genotype and 
anthelmintic treatment of ewes on Ostertagia spp populations. Int J Parasitol 12, 403-411.

6. Leyva V, Henderson AE \& Sykes AR (1982) Effect of daily infection with Ostertagia-circumcincta larvae on food-intake, milk-production and wool growth in sheep. J Agric Sci 99, 249-259.

7. Coop RL \& Kyriazakis I (1999) Nutrition-parasite interaction. Vet Parasitol 84, 187-204.

8. Houdijk JG, Kyriazakis I, Jackson F, Huntley JF \& Coop RL (2000) Can an increased intake of metabolizable protein affect the periparturient relaxation in immunity against Teladorsagia circumcincta in sheep? Vet Parasitol 91, 43-62.

9. Houdijk JGM, Kyriazakis I, Jackson F \& Coop RL (2001) The relationship between protein nutrition, reproductive effort and breakdown in immunity to Teladorsagia circumcincta in periparturient ewes. Anim Sci 72, 595-606.

10. Bisset SA, Morris CA, McEwan JC \& Vlassoff A (2001) Breeding sheep in New Zealand that are less reliant on anthelmintics to maintain health and productivity. N Z Vet J 49, 236-246.

11. Baker RL (1998) A review of genetic resistance to gastrointestinal nematode parasites in sheep and goats in the tropics and evidence for resistance in some sheep and goat breeds in subhumid coastal Kenya. Anim Genet Resour Inf Bull 24, 13-30.

12. Rauw WM, Kanis E, Noordhuizen-Stassen EN \& Grommers FJ (1998) Undesirable side effects of selection for high production efficiency in farm animals: a review. Livest Prod Sci 56, 15-33.

13. Ehrhardt RA, Slepetis RM, Bell AW \& Boisclair YR (2001) Maternal leptin is elevated during pregnancy in sheep. Domest Anim Endocrinol 21, 85-96.

14. Ingvartsen KL \& Boisclair YR (2001) Leptin and the regulation of food intake, energy homeostasis and immunity with special focus on periparturient ruminants. Domest Anim Endocrinol 21, 215-250.

15. Fantuzzi G (2005) Adipose tissue, adipokines, and inflammation. J Allergy Clin Immunol 115, 911-919.

16. Barbier M, Cherbut C, Aube AC, Blottiere HM \& Galmiche JP (1998) Elevated plasma leptin concentrations in early stages of experimental intestinal inflammation in rats. Gut $\mathbf{4 3}$, $783-790$.

17. Grunfeld C, Zhao C, Fuller J, Pollock A, Moser A, Friedman J \& Feingold KR (1996) Endotoxin and cytokines induce expression of leptin, the ob gene product, in hamsters - a role for leptin in the anorexia of infection. J Clin Invest 97, 2152-2157.

18. Valderrabano J, Gomez-Rincon C \& Uriarte J (2006) Effect of nutritional status and fat reserves on the periparturient immune response to Haemonchus contortus infection in sheep. Vet Parasitol 141, 122-131.

19. Houdijk JG, Kyriazakis I, Jackson F, Huntley JF \& Coop RL (2003) Is the allocation of metabolisable protein prioritised to milk production rather than to immune functions in Teladorsagia circumcincta-infected lactating ewes? Int J Parasitol 33, 327-338.

20. Tolkamp BJ, Yearsley JM, Gordon IJ, Illius AW, Speakman JR \& Kyriazakis I (2007) Predicting the effects of body fatness on food intake and performance of sheep. Br J Nutr 97, 1206-1215.

21. Agricultural and Food Research Council (1993) Energy and Protein Requirements of Ruminants. An Advisory Manual Prepared by the AFRC Technical Committee on Responses to Nutrients. Wallingford, UK: CAB International.

22. Russel AJF, Doney JM \& Gunn RG (1969) Subjective assessment of body fat in live sheep. $J$ Agric Sci 72, 451-454.

23. Glasbey CA, Abdalla I \& Simm G (1996) Towards automatic interpretation of sheep ultrasound scans. Anim Sci 62, 309-315.

24. Minson J (1990) Forage in Ruminant Nutrition. San Diego, CA: Academic Press.
25. Blaxter KL (1989) Energy Metabolism in Animals and Man. Cambridge: Cambridge University Press.

26. Christie M \& Jackson F (1982) Specific identification of strongyle eggs in small samples of sheep feces. Res Vet Sci 32, 113-117.

27. Paynter DI (1992) Pepsinogen Activity; Determination in Serum and Plasma. Australian Standard Diagnostic Techniques. Benalla, Australia: CSIRO, Standing Committee of Agriculture.

28. Zaralis K, Tolkamp BJ, Houdijk JGM, Wylie ARG \& Kyriazakis I (2008) Changes in food intake and circulating leptin due to gastrointestinal parasitism in lambs of two breeds. J Anim Sci 86, (In the Press).

29. Johnson LN, Kotz S \& Balakrishnan N (1998) Continuous Univariate Distributions, 2nd ed. Boston: PWS-KENT Publishing.

30. Good B, Hanrahan JP, Crowley BA \& Mulcahy G (2006) Texel sheep are more resistant to natural nematode challenge than Suffolk sheep based on faecal egg count and nematode burden. Vet Parasitol 136, 317-327.

31. Amarante AF, Bricarello PA, Rocha RA \& Gennari SM (2004) Resistance of Santa Ines, Suffolk and Ile de France sheep to naturally acquired gastrointestinal nematode infections. Vet Parasitol 120, 91-106.

32. Woolaston RR \& Baker RL (1996) Prospects of breeding small ruminants for resistance to internal parasites. Int J Parasitol 26, $845-855$.

33. Amarante AFT, Barbosa MA, Deoliveira M \& Siqueira ER (1992) Changes in fecal egg counts of gastrointestinal nematodes by ewes of 4 breeds in different reproductive status. Pesq Agrop Brasi 27, 47-51.

34. Donaldson J, van Houtert MFJ \& Sykes AR (1998) The effect of nutrition on the periparturient parasite status of mature ewes. Anim Sci 67, 523-533.

35. Chartier C, Etter E, Hoste H, Pors I, Mallereau MP, Broqua C, Mallet S, Koch C \& Masse A (2000) Effects of the initial level of milk production and of the dietary protein intake on the course of natural nematode infection in dairy goats. Vet Parasitol 92, 1-13.

36. Houdijk JGM, Jessop NS, Knox DP \& Kyriazakis I (2005) Secondary infection of Nippostrongylus brasiliensis in lactating rats is sensitive to dietary protein content. Br J Nutr 93, 493-499.

37. Greer AW, Stankiewicz M, Jay NP, McAnulty RW \& Sykes AR (2005) The effect of concurrent corticosteroid induced immunosuppression and infection with the intestinal parasite Trichostrongylus colubriformis on food intake and utilization in both immunologically naive and competent sheep. Anim Sci 80, 89-99.

38. Sykes AR \& Coop RL (1977) Intake and utilization of food by growing sheep with abomasal damage caused by daily dosing with Ostertagia-circumcincta larvae. J Agric Sci 88, 671-677.

39. Jeffcoate IA, Wedrychowicz H, Fishwick G, Dunlop EM, Duncan JL \& Holmes PH (1992) Pathophysiology of the periparturient egg rise in sheep - a possible role for IgA. Res Vet Sci 53, 212-218.

40. Sykes AR, Xie HL, Stankiewicz M, Huntley JF, Mackellar A, Sedcole JR, McAnulty RW \& Green R (2007) The effect of vaccinating infection during pregnancy and dietary protein supply on the peri-parturient immune response of sheep to infection with Teladorsagia circumcincta and Trichostrongylus colubriformis larvae. Animal 1, 249-260.

41. Stear MJ, Strain S \& Bishop SC (1999) Mechanisms underlying resistance to nematode infection. Int J Parasitol 29, 51-56.

42. Robinson JJ, Foster WH \& Forbes TJ (1969) Estimation of milk yield of a ewe from body weight data on suckling lamb. J Agric Sci 72, 103-107.

43. Van Soest PJ (1988) Nutritional Ecology of the Ruminant: Ruminant Metabolism, Nutritional Strategies, the Cellulolytic Fermentation and the Chemistry of Forages and Plant Fibres. Corvallis, Oregon: O \& B Books. 
44. van Dam JTP, Hofs P, Tolkamp BJ \& Zwart D (1998) The effect of the quality of roughage on the course of Trypanosoma vivax infection in West African dwarf goats - I. Organic matter intake, body weight change and efficiency of nitrogen metabolism. Livest Prod Sci 53, 69-80.

45. Sykes AR \& Field AC (1972) Effects of dietary deficiencies of energy, protein and calcium on pregnant ewe. 1. Body composition and mineral content of ewes. J Agric Sci 78, 109-117.

46. Houdijk JGM, Kyriazakis I, Coop RL \& Jackson F (2001) The expression of immunity to Teladorsagia circumcincta in ewes and its relationship to protein nutrition depend on body protein reserves. Parasitology 122, 661-672.

47. Lord GM, Matarese G, Howard LK, Baker RJ, Bloom SR \& Lechler RI (1998) Leptin modulates the T-cell immune response and reverses starvation-induced immunosuppression. Nature 394, 897-901.
48. La Cava A \& Matarese G (2004) The weight of leptin in immunity. Nat Rev Immunol 4, 371-380.

49. Chilliard Y, Bocquier F, Delavaud C, Faulconnier Y, Bonnet M, Guerre-Millo M, Martin P \& Ferlay A (1999) Leptin in ruminants. Nutritional and physiological factors of variation. Prod Anim 12, 225-237.

50. Delavaud C, Ferlay A, Faulconnier Y, Bocquier F, Kann G \& Chilliard Y (2002) Plasma leptin concentration in adult cattle: effects of breed, adiposity, feeding level, and meal intake. J Anim Sci 80, 1317-1328.

51. Tolkamp BJ, Emmans GC \& Kyriazakis I (2006) Body fatness affects feed intake of sheep at a given body weight. J Anim Sci 84, 1778-1789.

52. Ingvartsen KL \& Andersen JB (2000) Integration of metabolism and intake regulation: a review focusing on periparturient animals. J Dairy Sci 83, 1573-1597. 